\title{
Analiza częstości występowania oraz czynników wpływających na powstanie wad postawy u dzieci w wieku szkolnym
}

\author{
Analysis of appearing frequency and factors affecting \\ the occurrence of abnormal spinal curvatures at children \\ of primary school age \\ DOROTA KOCHMAN ${ }^{1}$ \\ ANETA STUDZIŃSKA ${ }^{2}$ \\ ${ }^{1}$ Państwowa Uczelnia Zawodowa we Włocławku, Instytut Nauk o Zdrowiu \\ 2 Centrum Diagnostyczno-Lecznicze Barska we Włocławku
}

DOI: http://dx.doi.org/10.21784/IwP.2020.016

ISSN: 2451-1846

\section{Streszczenie:}

Wstęp. Wada postawy definiowana jest jako zespół zaburzeń postawy charakteryzowanych jako minimalne indywidualne nieprawidłowości od odpowiedniej postawy ciała potencjalne do uzdrowienia profesjonalnymi ćwiczeniami biernymi i czynnymi. Ważną rolę w rozwoju nieprawidłowości postawy odgrywają czynniki nakłaniające do przyjęcia niepoprawnej sylwetki. Do wyżej wyszczególnionych czynników należą głównie: obieranie niewłaściwej postawy ciała podczas odpoczywania, niekomfortowo przyswojone miejsce do nauki, albo dźwiganie przeciążonych plecaków do szkoły. 
Cel pracy. Zobrazowanie powszechnego problemu wśród dzieci w wieku szkolnym jakim jest ujawnianie się wad postawy oraz wyszczególnienie czynników przyczyniających się do powstawania zaburzeń w postawie ciała.

Materiał i metody. W pracy wykorzystano metodę szacowania oraz metodę sondażu diagnostycznego. W celu wykonania badań ankietowych posłużono się anonimowym i zarazem autorskim formularzem ankietowym. W ankiecie wzięło udział 100 dzieci w wieku 11-14 lat u których obliczono wskaźnik BMI i oceniono parametry antropometryczne według siatek centylowych.

Wyniki. W badaniu udział wzięło 100 dzieci (49\% mężczyzn, 51\% kobiet). 24\% dzieci ma zdiagnozowaną wadę postawy, w tym 16 kobiet i 8 mężczyzn. Płaskostopie wykryto u 11 dzieci, co stanowi ok. 46\% osób z wadami postawy, natomiast koślawe kolana nie wystąpiły u żadnego dziecka (0\%). U 38\% dzieci, które na aktywność ruchową przeznaczają mniej niż godzinę dziennie zdiagnozowano wadę postawy, natomiast wśród grupy osób z dzienną aktywnością 1-2h występuje 16,1\% wad postawy. Z kolei u uczniów poświęcających ponad $2 \mathrm{~h}$ dziennie na aktywność nie stwierdzono żadnej wady. 87,5\% dzieci z nieprawidłowym poziomem wskaźnika BMI cierpi na wadę postawy. Dzieci (66\%), które nie przestrzegają prawidłowych zasad noszenia plecaka mają zdiagnozowaną wadę postawy.

Wnioski. W badanej grupie co czwarte dziecko ma zaburzenia w postawie ciała. Najczęstszym typem wady postawy jest płaskostopie, z kolei najrzadszym koślawe kolano. Wysunięto również konkluzję, że w badanej grupie niski poziom aktywności fizycznej wśród dzieci w wieku szkolnym oraz nieprawidłowe noszenie plecaka znacząco przyczynia się do powstawania zaburzeń postawy. Ponadto nieodpowiedni wynik BMI również ma negatywny wpływ na sylwetkę ciała dzieci.

Słowa kluczowe: wada postawy, wiek szkolny, BMI, postawa ciała, zaburzenie, aktywność fizyczna.

\section{Summary:}

Introduction. Faulty posture is define as the syndrome of bad posture that we characterize as minimal, individual anomalies upon proper poise which are potentially curable with professional passive and active exercises. An important function at develop posture anomalies has factors which induce to 
take improper silhouette. To the above factors mainly belong: bad posture while relaxation, wrong place to study or hefting overloaded packs.

Aim. Depiction of common problem among children at school age which is exposure of faulty posture and specification of factors which produce faulty posture.

Material and methods. In the thesis was used method of evaluation and diagnostic survey method. With the object of execution the questionnaire surveys applied an anonymous and authorial questionnaire at the same time. A hundred of children at 11-14 age entered the survey. Based on data, computed BMI rate and the anthropometric parameters were evaluated according to centile grid.

Results. A hundred of children entered the research (49\% boys, 51\% girls). $24 \%$ of children had diagnose of faulty posture namely 16 girls and 8 boys. Fallen arches was detected at 11 children, it is about $46 \%$ of people with bad posture, whereas none of children had knees valgus $(0 \%) .38 \%$ of children who are active less than hour per day were diagnosed with faulty posture, whereas group of people with 1-2 hours daily physical activity had only $16,1 \%$ of children with faulty posture. On the other hand with students who spare over two hours on activity daily were not any fault. 87,5\% of respondents with wrong BMI rate level suffer from bad posture. Children (66\%), who do not respect right rules of carrying pack have diagnosed faulty posture.

Conclusion. Every fourth child at research group has bad posture. The common type of faulty posture is fallen arches, but the rarest is knee valgus. Low level of physical activity and wrong way of carrying pack significantly contribute to develop faulty posture among school age children. Furthermore inadequate result of BMI also has negative impact on body posture of child.

Keywords: faulty posture, school age, BMI, poise, disability, physical.

\section{Wstęp}

W literaturze źródłowej istnieje wiele różnorodnych definicji wad postawy. Dega wadę postawy określa jako zbiór nieprawidłowości postawy określanych jako nieznaczne jednostkowe zaburzenie od optymalnej postawy ciała możliwe do reformowania specjalistycznymi 
ćwiczeniami biernymi i czynnymi. W zakresie prewencji badań lekarskich rozpoznaje się u młodych osób różne wady postawy. Ze względu na wysoką częstotliwość ujawniania się problemów związanych z prawidłową postawą ciała wśród dzieci, a także możność wprowadzenia efektywnych działań profilaktycznych, niezbędne jest rychłe zdiagnozowanie wady postawy za pomocą prawidłowo wykonanych badań lekarskich. Istotne znaczenie $w$ rozkwicie wady postawy kreują czynniki przyczyniające się do przyjmowania nieodpowiedniej postawy ciała. Należą do nich między innymi: przyjmowanie nieprawidłowych pozycji w czasie odpoczynku, nieodpowiednio dopasowane miejsce przeznaczone do nauki czy noszenie przeciążonych tornistrów. Według badań Health Behaviour in School-aged Children dotyczących stanu zdrowia dzieci na kontynencie europejskim współpracującym w naszym kraju z Instytutem Matki i Dziecka aktualnie wyraźnie rośnie ilość czynników przyczyniających się do tworzenia wad postawy. Zauważalnym zjawiskiem jest coraz większy udział czynności wymagających niskiego nakładu energetycznego przejawiających się zazwyczaj w pozycji siedzącej, do których zalicza się oglądanie telewizji czy praca przed komputerem. Coraz mniejsze znaczenie aktywności fizycznej należy do czynników wpływających na powstawanie wad postawy i jednocześnie umacniających występujące już wcześniej zaburzenia [1].

Częstotliwość ujawniania się wad postawy zobowiązuje wszelkich osób odpowiedzialnych za wychowywanie dzieci do wnikliwego sprawdzania postawy dzieci, czynności zapobiegawczych skierowanych na kosmetykę sylwetki, a także przeciwdziałania inicjowania wad [2].

\section{Cel}

Celem niniejszej pracy jest ocena częstości występowania oraz analiza czynników przyczyniających się do powstania wad postawy u dzieci w wieku 11-14 lat. 


\section{Materiał i metody}

Badaną populacją było 100 dzieci chłopców (49\%) i dziewcząt (51\%) uczęszczających do Szkoły Podstawowej. Pod względem wiekowym respondentów podzielono na 4 grupy wiekowe: 11 r.ż.(37\%), 12 r.ż.(24\%), 13 r.ż.(17\%) oraz 14 r.ż.(22\%). Większość badanych zamieszkiwało wieś $-98,0 \%$.

W pracy wykorzystano metodę szacowania oraz metodę sondażu diagnostycznego. W celu wykonania badań ankietowych posłużono się anonimowym i zarazem autorskim formularzem ankietowym. Współzależność pomiędzy dwiema zmiennymi, obliczono za pomocą współczynnik korelacji R Spearmana. W pracy zastosowano również nieparametryczny Test rang Kruskala-Wallisa, stosowany do porównania wielu prób niezależnych (grup).

\section{Wyniki}

Wynik średni masy ciała wyniósł - 48,7 kg. Odchylenie standardowe stanowiło ponad $26,4 \%$ wartości średniej, co świadczy o przeciętnym zróżnicowaniu wyników masy ciała. Najwyższy średni wynik odnotowano w grupie 14 lat $-59,6 \mathrm{~kg}$ oraz 13 lat $-54,2 \mathrm{~kg}$. Najniższy w wieku 11 lat - 41,4 kg. Najwięcej uczniów uzyskało wynik 75-90 centyla $-23,0 \%$ oraz $50-75$ centyla $-15,0 \%$ i $25-50$ centyla $-13,0 \%$. Najmniej wynik 10 centyla $3,0 \%$. 


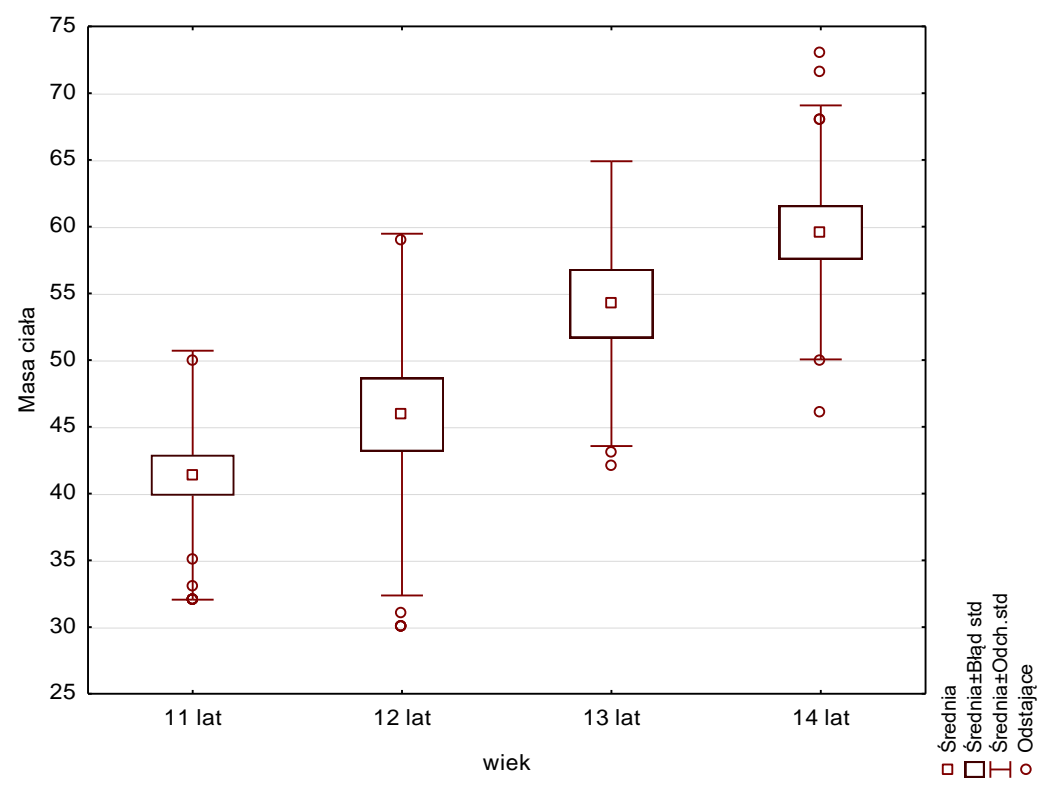

Ryc. 1. Rozkład wyników średnich wagi w grupach wiekowych.

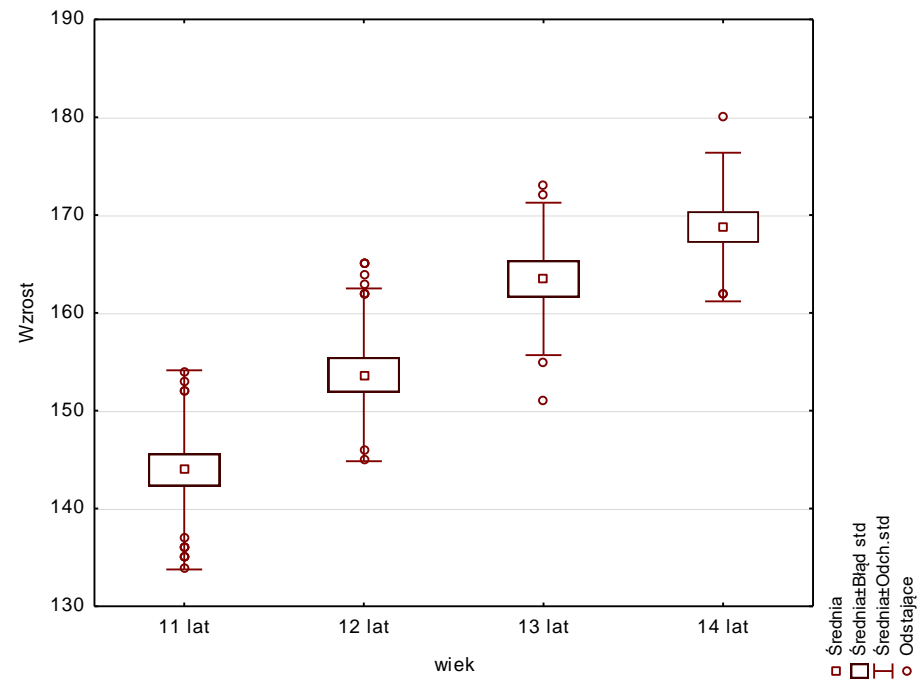

Ryc. 2 Rozkład wyników średnich wzrostu w grupach wiekowych. 
Wynik średni wzrostu wyniósł - 155,1 cm. Odchylenie standardowe stanowiło ponad 8,6\% wartości średniej, co świadczy o nieznacznym zróżnicowaniu wyników wzrostu. Najwyższy średni wynik odnotowano w grupie 14 lat $-168,8 \mathrm{~cm}$ oraz 13 lat $-163,5 \mathrm{~cm}$. Najniższy w wieku 11 lat - 143,9 cm. Najwięcej uczniów uzyskało wynik 25-50 centyla $-15,0 \%$ oraz 75-90 centyla - 12,0\% i 50-75 centyla - 10,0\%. Najmniej wynik to 10 i 25 centyla po 1,0\%.

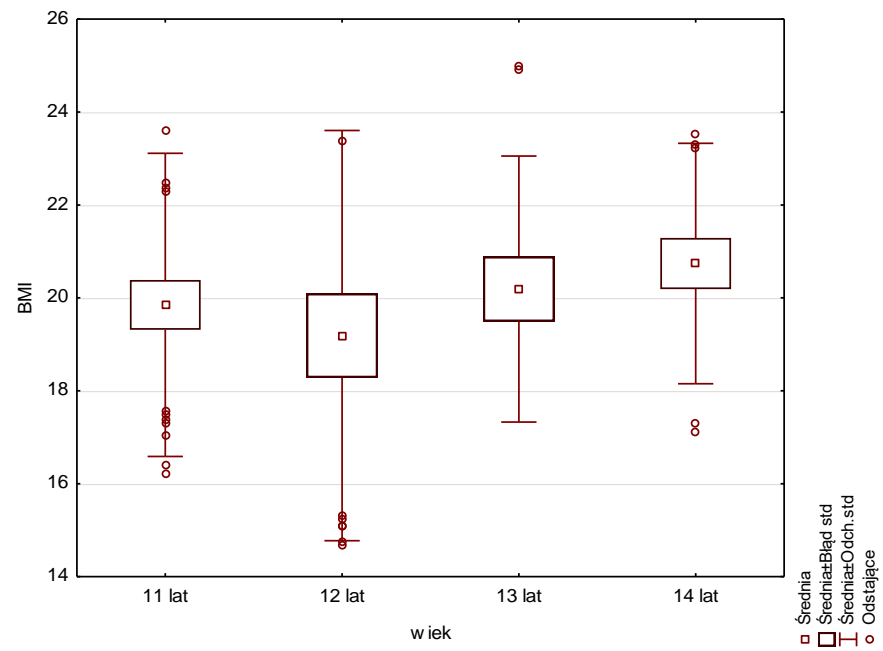

Ryc. 3. Rozkład wyników średnich BMI w grupach wiekowych.

Wynik średni BMI wyniósł - 19,94 punktu. Odchylenie standardowe stanowiło ponad 16,9\% wartości średniej, co świadczy o nieznacznym zróżnicowaniu wyników BMI. Najwyższy średni wynik odnotowano w grupie 14 lat - 20,74 punktu oraz 13 lat - 20,19 punktu. Najniższy w wieku 12 lat - 19,19 punktu. Najwięcej uczniów uzyskało wynik 50-85 centyla - 34,0\% oraz 97 i $85-97$ centyla - po $16,0 \%$. Najmniej wynik 10, 15 i 50 centyla po 3,0\%. 
Najliczniejszą grupę stanowili badani z otyłością - 59,0\%, następnie badani z nadwagą - 21,0\%, kolejno badani z prawidłową masą ciała - 19,0\%, najmniej liczną z niedowagą - 1,0\%. Do dalszej analizy, osoba ta zakwalifikowana zostanie do grupy wartości prawidłowej.

Ze względu na poziom istotności ( $p>0,05)$, nie odnotowano istotnej statystycznie różnicy pomiędzy kobietami i mężczyznami, dotyczącej wyników wskaźnika BMI.

Wiek badanych uczniów, nie pozostawał w istotnej statystycznie korelacji z wynikami wskaźnik BMI $(\mathrm{p}>0,05)$. Wynik na granicy istotności.

\section{Analiza czynników wpływających na wady postawy u dzieci w wieku szkolnym}

Najwięcej badanych wskazało, że podczas wykonywania różnych czynności o prawidłowej postawie ciała pamięta czasami - 54,0\%, zawsze 39\%. Najmniej wskazało, że nie pamięta - 7,0\%.

Na oglądanie TV młodzież poświęca dziennie 1-2 godzin - 46,0\%, do $1 \mathrm{~h}-40 \%$. Najmniej wskazało, że powyżej 2 godzin -14,0\%.

Na korzystanie z komputera młodzież poświęca dziennie 1-2 godzin - 42,0\%, powyżej $2 \mathrm{~h}-32 \%$. Najmniej wskazało, że do 1 godziny $26,0 \%$.

Przestrzeganie zasady, iż plecak nie może ważyć więcej niż 10$15 \%$ masy ciała wskazało - 58,0\%, zaś zasady, że plecak powinien mieć usztywnioną ściankę przylegającą do pleców oraz równe, szerokie szelki - 77,0\%.

Duża grupa młodzieży wskazała, że przestrzega zasady iż cięższe rzeczy powinny być umieszczane na dnie, lżejsze wyżej - 58,0\%, zaś zasady, iż tornister należy nosić na obu ramionach - 82,0\%.

Najwięcej uczniów wskazało, że nie uczestniczy w zajęciach wychowania fizycznego tylko w sytuacji zwolnienia lub nieprzygotowania 
do zajęć - 75,0\%, najmniej wskazało, że jeden raz w tygodniu nie ćwiczy - 11,0\%, pozostała grupa więcej niż raz w tygodniu.

Na aktywność fizyczną w ciągu dnia najwięcej uczniów poświęca poniżej jednej godziny - 50,0\%, od 1 do $2 \mathrm{~h} 31 \%$ dzieci najmniej wskazało, że powyżej dwóch godzin - 19,0\%.

Najwięcej badanych stwierdziło, że rodzice czasami zwracają uwagę na sposób ich siedzenia, chodzenia oraz noszenia tornistra $45,0 \%$, często robi to $32 \%$ rodziców, najmniej wskazało, że nie zwracają uwagi $-23,0 \%$.

Na sen najwięcej uczniów dziennie poświęca 9-10 godzin - 56,0\%, poniżej $8 \mathrm{~h}-38 \%$, najmniej powyżej 10 godzin - 6,0\%.

Najwięcej uczniów - 46,0\% w badanej próbie nie robi w ogóle przerwy na aktywność ruchową podczas odrabiania lekcji lub robi to co 30 minut - 33,0\%, najmniej co 2 godziny - 8,0\%.

Najwięcej młodzieży wskazało, że nosi odzież lekką, nie krępującej ruchów - 87,0\%.

0 prawidłowym oświetleniu podczas odrabiania prac domowych pamięta najwięcej badanych, tak wskazało - 89,0\%, najmniej stwierdziło, że nie - $1,0 \%$

Najbliższe osoby z otoczenia badanych pamiętają zawsze lub tylko czasami o prawidłowej postawie ciała stwierdziło tak - $63,0 \%$ pozostałe nie dostrzegają takich sytuacji.

Dość mała grupa młodzieży - 16,0\% wskazała, że odczuwa nieprawidłowości w narządach wzroku i słuchu., a złamania i unieruchomienia kończyny doświadczyło $28,0 \%$ badanych.

Najwięcej badanych wskazało, że rodzice kupując dla nich obuwie zwracają uwagę na odpowiednią długość, szerokość, kształt oraz materiał obuwia - 77,0\%, najmniej stwierdziło, że nie - 8,0\%, pozostałe stwierdziły, że tylko czasami. 
Prawidłowo i regularnie odżywia się - 56,0\%, najmniej stwierdziło, że robi to nie prawidłowo - 8,0\%, pozostałe robią to tylko czasem.

Najwięcej uczniów wskazało, że nie wie czy w rodzinie występowały wady postawy - 39,0\%, najmniej było zdania, że tak - 23,0\%.

Tab. 1. Zróżnicowanie wyników zagadnień dotyczących postawy pomiędzy grupami płci.

\begin{tabular}{|l|c|c|c|c|c|c|c|c|c|c|}
\hline $\begin{array}{c}\text { Pozy- } \\
\text { cja }\end{array}$ & $\begin{array}{c}\text { Sum. } \\
\text { Rang } \\
\text { kobieta }\end{array}$ & $\begin{array}{c}\text { Sum. } \\
\text { Rang } \\
\text { męż- } \\
\text { czyzna }\end{array}$ & U & Z & $\begin{array}{c}\text { Poziom } \\
\mathrm{p}\end{array}$ & Z popr & $\begin{array}{c}\text { Poziom } \\
\mathrm{p}\end{array}$ & $\begin{array}{c}\text { N ważn } \\
\text { kobieta }\end{array}$ & $\begin{array}{c}\text { N ważn } \\
\text { męż- } \\
\text { czyzna }\end{array}$ & $\begin{array}{c}\text { 2*1str. } \\
\text { dokł. p }\end{array}$ \\
\hline $\begin{array}{l}\text { Dzien } \\
\text { na } \\
\text { ilość } \\
\text { godzin } \\
\text { prze- } \\
\text { zna- } \\
\text { czona } \\
\text { na ko- } \\
\text { rzy- } \\
\text { stanie } \\
\text { z kom- } \\
\text { putera }\end{array}$ & \begin{tabular}{c}
2078, \\
2971, \\
\hline
\end{tabular} & 552,5 & $-3,423$ & 0,001 & $-3,658$ & 0,000 & 51 & 49 & 0,001 \\
\hline
\end{tabular}

Ze względu na poziom istotności $(\mathrm{p}<0,05)$, odnotowano istotną statystycznie różnicę pomiędzy kobietami i mężczyznami, dotyczącą wyników zagadnienia dzienna ilość godzin przeznaczona na korzystanie z komputera. 


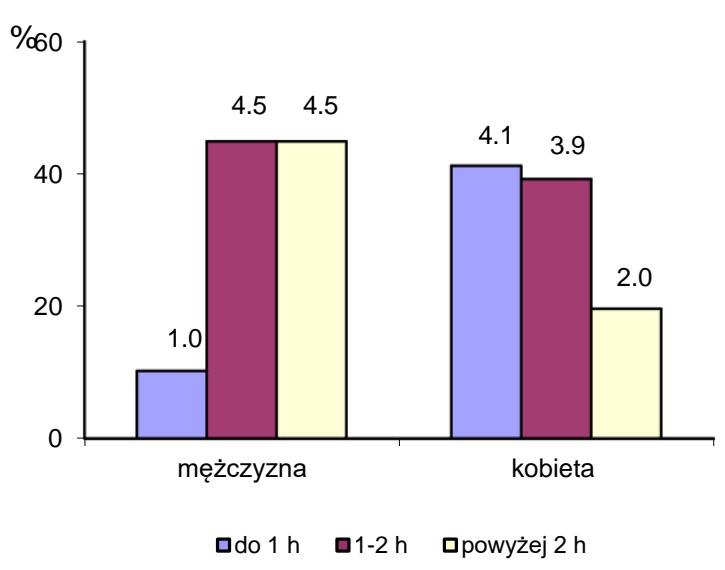

Ryc. 4. Rozkład dziennej ilości czasu poświęcanego na korzystanie z komputera w grupach płci.

Najwięcej mężczyzn na korzystanie $\mathrm{z}$ komputera poświęcało dziennie 1-2 godzin lub powyżej 2 godzin - po 22 osoby (po 44,9\%). Najwięcej kobiet wskazało, że do 1 godziny - 21 osób (41,2\%), najmniej powyżej 2 godzin - 10 osób (19,6\%). Generalnie więcej czasu dziennie przed komputerem spędzali mężczyźni.

Tab. 2. Korelacje wieku i wyników zagadnień dotyczących postawy.

\begin{tabular}{|l|c|c|c|c|}
\hline \multicolumn{1}{|c|}{ Pozycja } & $\mathrm{N}$ & $\mathrm{R}$ & $\mathrm{t}(\mathrm{N}-2)$ & Poziom p \\
\hline $\begin{array}{l}\text { Czy rodzice zwracają uwagę na } \\
\text { to co jest w tornistrze }\end{array}$ & 100 & 0,294 & 3,048 & 0,003 \\
\hline $\begin{array}{l}\text { Czy miałeś złamaną i unierucho- } \\
\text { mioną kończynę }\end{array}$ & 100 & $-0,203$ & $-2,053$ & 0,043 \\
\hline
\end{tabular}

Wiek badanych uczniów, pozostawał w istotnej statystycznie, niskiej korelacji z wynikami zagadnień czy rodzice zwracają uwagę na to co jest w tornistrze oraz czy miałeś złamaną i unieruchomioną kończynę $(\mathrm{p}<0,05)$. 


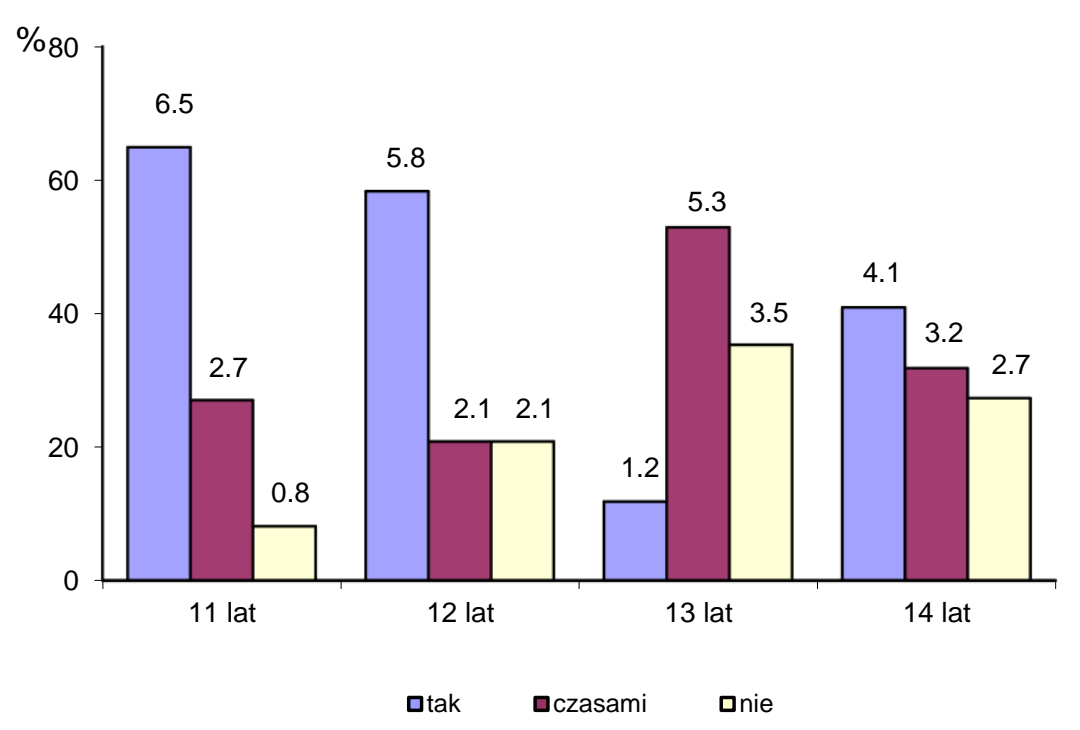

Ryc. 5. Rozkład zwracania uwagi przez rodziców na to co znajduje się w tornistrze w grupach wiekowych.

Najwięcej uczniów w wieku 11 lat wskazało, że rodzice zwracają uwagę na to co znajduje się w tornistrze - 24 osoby $(64,9 \%)$. Dalej w wieku 12 lat - 14 osób (58,3\%). W najmniejszym stopniu w wieku 13 lat - 2 osoby $(11,8 \%)$.

Na doświadczenie złamania i unieruchomienia kończyny wskazali w największym stopniu uczniowi w wieku 13 lat - 7 osób $(41,2 \%)$ oraz w wieku 14 lat - 8 osób (36,4\%). W najmniejszym stopniu w wieku 11 lat - 6 osób $(16,2 \%)$. 
Tab. 3. Różnice w wynikach zagadnień dotyczących postawy pomiędzy grupami wskaźnika BMI.

\begin{tabular}{|l|c|c|c|}
\hline \multicolumn{1}{|c|}{ Pozycja } & $\mathrm{df}$ & $\mathrm{H}=$ & Poziom p \\
\hline $\begin{array}{l}\text { Pamiętanie o prawidłowej postawie ciała } \\
\text { podczas wykonywania różnych czynności }\end{array}$ & $(2, \mathrm{~N}=100)$ & 6,610 & 0,037 \\
\hline $\begin{array}{l}\text { Co jaki czas podczas odrabiani lekcji ro- } \\
\text { bisz przerwy na aktywność ruchową }\end{array}$ & $(2, \mathrm{~N}=100)$ & 8,927 & 0,012 \\
\hline
\end{tabular}

Ze względu na poziom istotności $(\mathrm{p}<0,05)$, odnotowano statystycznie istotne różnice pomiędzy grupami wskaźnika BMI dotyczące wyników pamiętanie o prawidłowej postawie ciała podczas wykonywania różnych czynności oraz co jaki czas podczas odrabiani lekcji robisz przerwy na aktywność ruchową.

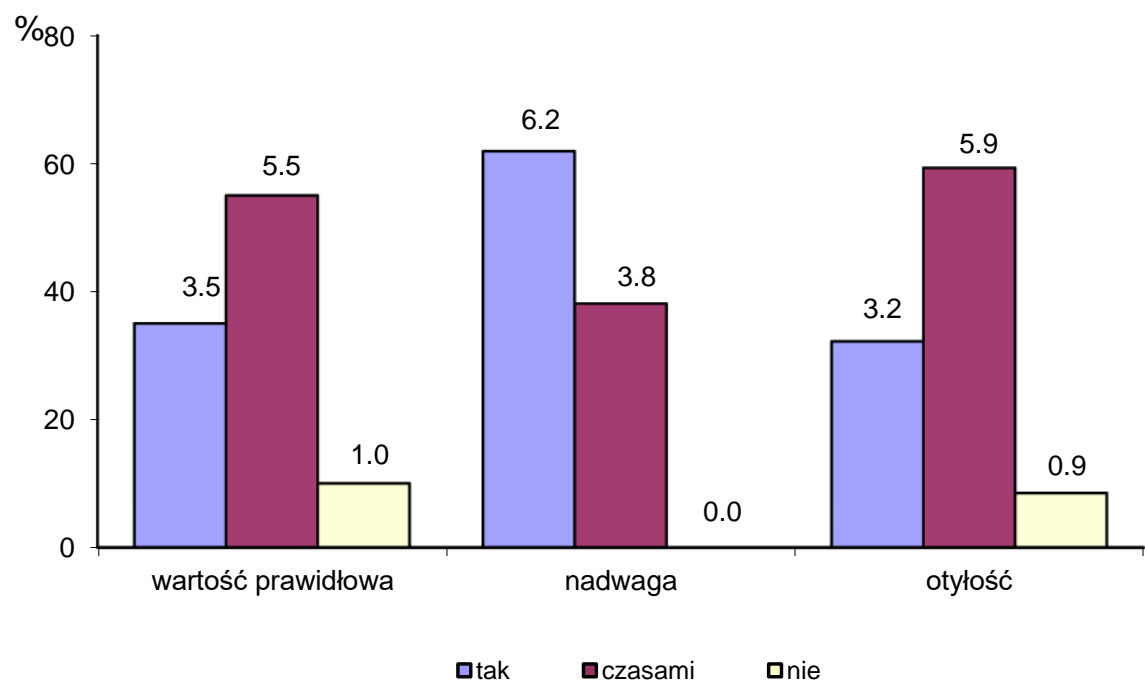

Ryc. 6. Rozkład pamiętania o prawidłowej postawie ciała podczas wykonywania różnych czynności w grupach BMI. 
Najwięcej badanych z nadwagą wskazało, że podczas wykonywania różnych czynności o prawidłowej postawie ciała pamięta - 13 osób $(61,9 \%)$. Najmniej w grupie z otyłością - 19 osób $(32,2 \%)$.

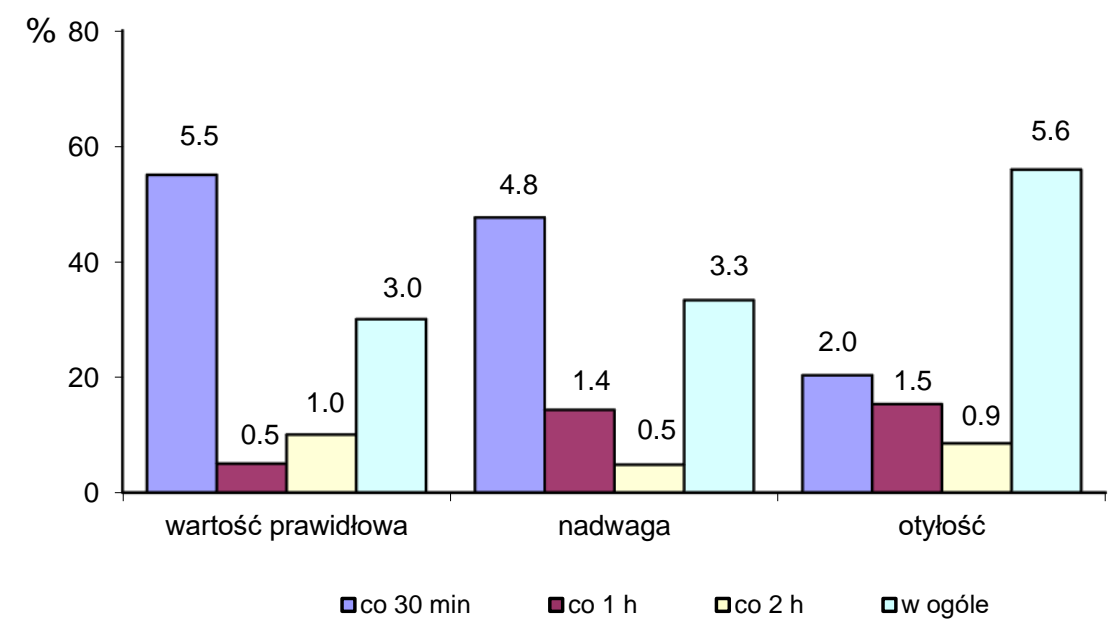

Ryc. 7. Rozkład częstości robienia przerw na aktywność ruchową podczas odrabiania lekcji w grupach BMI.

Najwięcej uczniów z wartością prawidłową BMI przerwę na aktywność ruchową podczas odrabiania lekcji robiło co 30 minut - 11 osób (55,0\%), najmniej co 1 godzinę - 1 osoba (5,0\%). W grupie z nadwagą najwięcej co 30 minut - 10 osób $(47,6 \%)$, najmniej co 2 godziny - 1 osoba $(4,8 \%)$. W grupie z otyłością najwięcej nie robiło przerwy w ogóle - 33 osoby $(55,9 \%)$, najmniej co 2 godziny - 5 osób $(8,5 \%)$. 


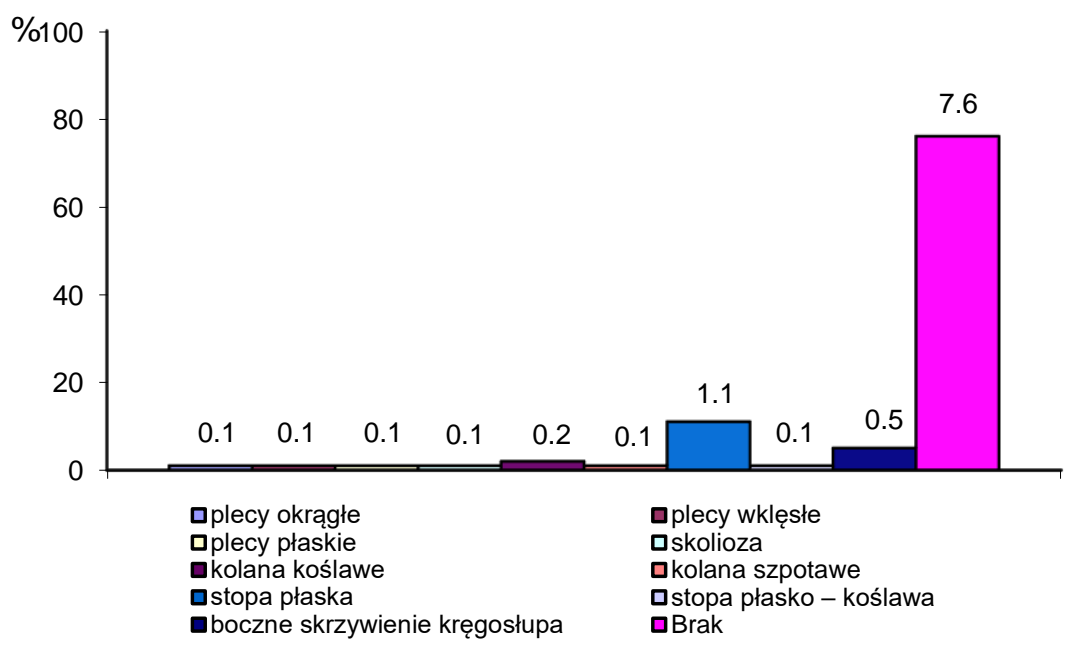

Ryc. 8. Rozkład zdiagnozowanych wad postawy.

Generalnie większość badanych nie miał wady postawy - 76,0\%. Wśród pozostałych najwięcej miało stopę płaską - 11,0\% lub boczne skrzywienie kręgosłupa - 5,0\% oraz kolana koślawe - 2,0\%. Pozostałe to przypadki jednostkowe.

Tab. 4. Różnice w wynikach wad postawy pomiędzy grupami płci.

\begin{tabular}{|l|c|c|c|c|c|c|c|c|c|c|}
\hline $\begin{array}{c}\text { Po- } \\
\text { zycja }\end{array}$ & $\begin{array}{c}\text { Sum. } \\
\text { Rang } \\
\text { kobieta }\end{array}$ & $\begin{array}{c}\text { Sum. } \\
\text { Rang } \\
\text { męż- } \\
\text { czyzna }\end{array}$ & $\mathrm{U}$ & $\mathrm{Z}$ & $\begin{array}{c}\text { Poziom } \\
\mathrm{p}\end{array}$ & $\mathrm{Z}$ popr & $\begin{array}{c}\text { Poziom } \\
\mathrm{p}\end{array}$ & $\begin{array}{c}\text { N ważn } \\
\text { kobieta }\end{array}$ & $\begin{array}{c}\text { N ważn } \\
\text { męż- } \\
\text { czyzna }\end{array}$ & $\begin{array}{c}2 * 1 \text { str. } \\
\text { dokł. p }\end{array}$ \\
\hline $\begin{array}{l}\text { wy- } \\
\text { stą- } \\
\text { pie- } \\
\text { nie } \\
\text { wad }\end{array}$ & $\begin{array}{c}2363, \\
\text { y }\end{array}$ & $\begin{array}{c}2686, \\
5\end{array}$ & 5 & $-1,458$ & 0,145 & $-1,971$ & 0,049 & 51 & 49 & 0,144 \\
\hline $\begin{array}{l}\text { zdia } \\
\text { gno- } \\
\text { zow }\end{array}$ & 107,0 & 193,0 & 57,0 & 0,398 & 0,691 & 0,421 & 0,674 & 8 & 16 & 0,697 \\
$\begin{array}{l}\text { wad } \\
\text { a }\end{array}$
\end{tabular}


Ze względu na poziom istotności $(\mathrm{p}<0,05)$, odnotowano statystycznie istotną różnicę pomiędzy mężczyznami i kobietami, dotyczącą wyników wystąpienia wady postawy.

Dwukrotnie częściej wady postawy występowały w grupie kobiet - 16 osób (32,7\%), grupie mężczyzn - 8 osób $(15,7 \%)$.

Wiek badanych, nie pozostawał w istotnej statystycznie korelacji zarówno z wynikami wystąpienia wad postawy jak i rodzajem wady $(p>0,05)$.

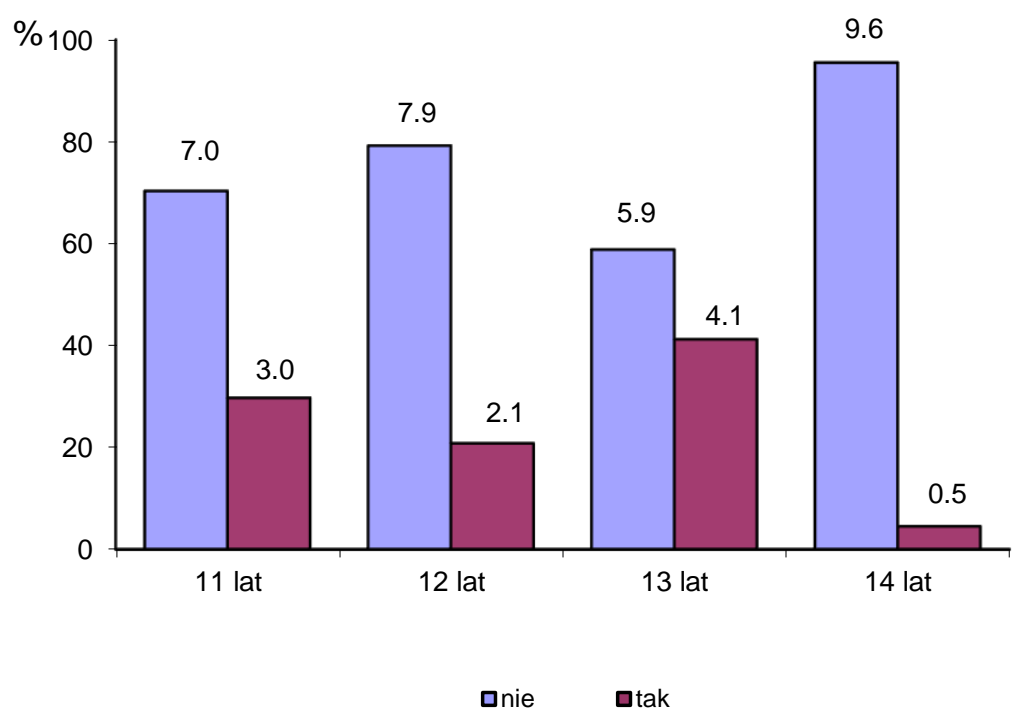

Ryc. 9. Rozkład wyników wystąpienia wad postawy w grupach wiekowych.

W największym stopniu wady postawy występowały w grupie 13 lat - 7 osób $(41,2 \%)$ oraz 11 lat - 11 osób (29,7\%). W najmniejszym stopniu w wieku 14 lat -1 osoba $(4,5 \%)$. 
Tab. 5. Różnice w wynikach wystąpienia wady postawy pomiędzy grupami wskaźnika BMI.

\begin{tabular}{|l|c|c|c|}
\hline \multicolumn{1}{|c|}{ Pozycja } & $\mathrm{df}$ & $\mathrm{H}=$ & Poziom $\mathrm{p}$ \\
\hline Wystąpienie wady & $(2, \mathrm{~N}=100)$ & 5,423 & 0,066 \\
\hline $\begin{array}{l}\text { Zdiagnozowana } \\
\text { wada }\end{array}$ & $(2, \mathrm{~N}=24)$ & 6,436 & 0,040 \\
\hline
\end{tabular}

Ze względu na poziom istotności $(\mathrm{p}<0,05)$, odnotowano statystycznie istotną różnicę pomiędzy grupami wskaźnika BMI dotyczącą wyników rodzaju zdiagnozowanej wady postawy.

Tab. 6. Wyniki wystąpienia wady postawy w grupach BMI.

\begin{tabular}{|l|c|c|c|c|c|c|}
\hline \multicolumn{1}{|c|}{ BMI } & \multicolumn{2}{c|}{$\begin{array}{c}\text { wartość prawi- } \\
\text { dłowa }\end{array}$} & \multicolumn{2}{c|}{ nadwaga } & \multicolumn{2}{c|}{ otyłość } \\
\hline \multicolumn{1}{|c|}{ wada postawy } & liczba & $\%$ & liczba & $\%$ & liczba & $\%$ \\
\hline plecy okrągłe & 1 & 33,3 & 0 & 0,0 & 0 & 0,0 \\
\hline plecy wklęsłe & 1 & 33,3 & 0 & 0,0 & 0 & 0,0 \\
\hline plecy płaskie & 0 & 0,0 & 0 & 0,0 & 1 & 5,3 \\
\hline skolioza & 0 & 0,0 & 0 & 0,0 & 1 & 5,3 \\
\hline kolana koślawe & 0 & 0,0 & 1 & 50,0 & 1 & 5,3 \\
\hline kolana szpotawe & 1 & 33,3 & 0 & 0,0 & 0 & 0,0 \\
\hline stopa płaska & 0 & 0,0 & 0 & 0,0 & 11 & 57,9 \\
\hline stopa płasko - koślawa & 0 & 0,0 & 0 & 0,0 & 1 & 5,3 \\
\hline $\begin{array}{l}\text { boczne skrzywienie } \\
\text { kręgosłupa }\end{array}$ & 0 & 0,0 & 1 & 50,0 & 4 & 21,1 \\
\hline Razem & 3 & 100,0 & 2 & 100,0 & 19 & 100,0 \\
\hline
\end{tabular}


Większość zdiagnozowanych wad postawy wystąpiła w grupie z otyłością w największym stopniu stopa płaska - 11 osób $(57,9 \%)$ oraz boczne skrzywienie kręgosłupa - 4 osoby $(21,1 \%)$.

Tab. 7. Korelacje dziennej ilości czasu poświęcanego na aktywność fizyczną i wyników wad postawy.

\begin{tabular}{|l|c|c|c|c|}
\hline \multicolumn{1}{|c|}{ Pozycja } & $\mathrm{N}$ & $\mathrm{R}$ & $\mathrm{t}(\mathrm{N}-2)$ & Poziom p \\
\hline Wystąpienie wady & 100 & $-0,352$ & $-3,724$ & 0,000 \\
\hline $\begin{array}{l}\text { Zdiagnozowana } \\
\text { wada }\end{array}$ & 24 & $-0,337$ & $-1,678$ & 0,108 \\
\hline
\end{tabular}

Dzienna ilość czasu poświęcana na aktywność fizyczną pozostawał w istotnej statystycznie, średniej korelacji z wynikami wystąpienia wad postawy $(\mathrm{p}<0,05)$.

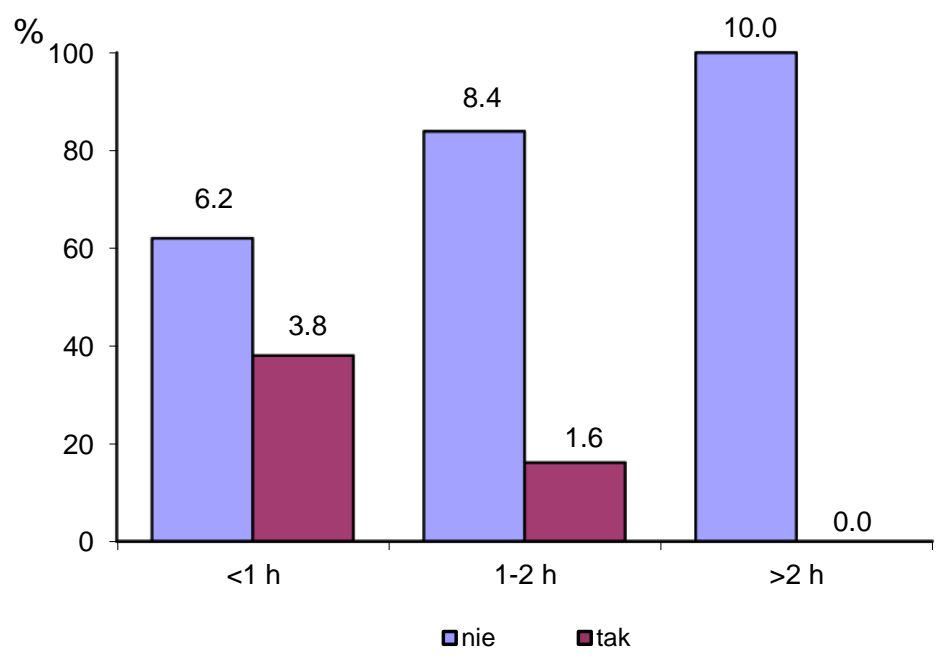

Ryc. 10. Rozkład wyników wystąpienia wad postawy w grupach dziennej ilości czasu poświęcanego na aktywność fizyczną. 
W największym stopniu wady postawy występowały w grupie poświęcających dziennie na aktywność fizyczna <1 godziny - 19 osób $(38,0 \%)$. Nie występowały w grupie poświęcających $>2$ godzin.

Tab. 8. Różnice w wynikach wad postawy pomiędzy grupami przestrzegania zasad noszenia plecaka.

\begin{tabular}{|c|c|c|c|c|c|c|c|c|c|c|}
\hline $\begin{array}{l}\text { Po- } \\
\text { zy- } \\
\text { cja }\end{array}$ & $\begin{array}{c}\text { Sum. } \\
\text { Rang } \\
\text { tak }\end{array}$ & $\begin{array}{c}\text { Sum. } \\
\text { Rang } \\
\text { nie }\end{array}$ & U & Z & $\begin{array}{c}\text { Poziom } \\
\mathrm{p}\end{array}$ & Z popr. & $\begin{array}{c}\text { Poziom } \\
\mathrm{p}\end{array}$ & $\begin{array}{c}\mathrm{N} \text { ważn } \\
\text { tak }\end{array}$ & $\begin{array}{c}\mathrm{N} \text { ważn } \\
\text { nie }\end{array}$ & $\begin{array}{l}2 * 1 \text { str. } \\
\text { dokł. }\end{array}$ \\
\hline $\begin{array}{l}\text { wy- } \\
\text { stą- } \\
\text { pie- } \\
\text { nie } \\
\text { wad } \\
\text { y }\end{array}$ & $\begin{array}{c}2902 \\
5\end{array}$ & $\begin{array}{c}2147, \\
5\end{array}$ & 757,5 & $-2,743$ & 0,006 & $-3,707$ & 0,000 & 65 & 35 & 0,006 \\
\hline $\begin{array}{l}\text { zdia } \\
\text { gno- } \\
\text { zo- } \\
\text { wan } \\
\text { a } \\
\text { wad } \\
\text { a }\end{array}$ & 73,5 & 226,5 & 37,5 & $-1,592$ & 0,111 & $-1,683$ & 0,092 & 8 & 16 & 0,106 \\
\hline
\end{tabular}

Ze względu na poziom istotności $(\mathrm{p}<0,05)$, odnotowano statystycznie istotną różnicę pomiędzy grupami przestrzegania zasad noszenia plecaka, dotyczącą wyników wystąpienia wady postawy. Wynik rodzaju zdiagnozowanej wady postawy, na granicy istotności.

W większym stopniu wady postawy występowały w grupie nie przestrzegających prawidłowych zasad noszenia plecaka - 16 osób $(45,7 \%)$, zaś w grupie przestrzegających zasady - 8 osób $(12,3 \%)$.

\section{Dyskusja}

Postawa ciała oddziałuje na swoistą cechę danej osoby, jaką jest sylwetka. Z kolei sylwetka kształtowana jest między innymi poprzez stan zdrowia człowieka czy jego samopoczucie. Najistotniejszym 
elementem dotyczącym formowania się prawidłowej postawy człowieka jest przybieranie odpowiednich nawyków fizycznych od wieku dziecięcego. Jednakże ważne jest dbanie o prawidłową postawę także w dorosłym życiu. W celu ograniczenia ujemnych efektów działań środowiskowych trzeba poświęcać dużą uwagę odpowiedniej strukturze ciała, co jest w sposób bezpośredni powiązane ze stanem zdrowia [3].

Otoczenie szkolne w istotny sposób rzutuje na regularny rozwój dziecka, głównie troszcząc się o jego rozwój psychofizyczny. Mało aktywny tryb życia, a także długotrwałe przebywanie przed komputerem powoduje wzrost liczby młodych osób dotkniętych nadwagą i otyłością. Za pojęciem postawy ciała kryje się ułożenie pojedynczych odcinków ciała, jakie osoba przyjmuje w nieskrępowanej pozycji stojącej. Ponadto taka pozycja uzależniona jest od przyzwyczajeń fizycznych oraz czynników morfologicznych i funkcjonalnych. Do czynników wpływających na postawę ciała zaliczamy miedzy innymi: wiek, rodzaj płci, prowadzony tryb życia, aktywność fizyczną czy typ wykonywanej pracy [4].

Z przeprowadzonych badań własnych wynika, że około jedna czwarta uczniów, a dokładnie $24 \%$ ma zdiagnozowaną wadę postawy, w tym 16 kobiet i 8 mężczyzn. Z kolei z badań przeprowadzonych przez Wilmańską w klasach I-III na 285 dzieci przebadanych wykryto 194 dzieci z wadą postawy, co daje $68 \%$ uczniów [5].

Najczęstszym rodzajem wad postawy spośród przebadanej populacji jest płaskostopie, które wykryto u 11 dzieci, co stanowi ok. 46\% osób z wadami postawy. W badaniach Białoszewskiego, w których udział brali rodzice wynika, że deformacje stóp oraz płaskostopie ma ok. 24\% ich dzieci, co daję największą grupę nieprawidłowości w układzie ruchu [5].

Najrzadziej występującą wadą postawy w grupie badanych osób są koślawe kolana (0\%). Nikt w analizowanej dokumentacji nie miał zdiagnozowanych koślawych kolan. Analizowana wada postawy 
znajduje się w grupie czterech wad, które nie występują wśród badanych. Wśród wymienionych typów wad postawy, zgodnie z badaniami Maciałczyk-Paprockiej, przeprowadzonymi na dzieciach w wieku 7-12 lat, najrzadziej występującą wadą postawy były kolana szpotawe (1\%) [4].

Z przeprowadzonych ankiet wynika, że im mniej czasu dzieci w wieku 11-14 lat poświęcają na aktywność fizyczną tym częściej diagnozuje się wady postawy. U 38\% dzieci, które na aktywność ruchową przeznaczają mniej niż godzinę dziennie zdiagnozowano wadę postawy, natomiast wśród grupy osób $\mathrm{z}$ dzienną aktywnością 1-2h występuje 16,1\% wad postawy. Z kolei u uczniów poświęcających ponad $2 \mathrm{~h}$ dziennie na aktywność nie stwierdzono żadnej wady $(\mathrm{p}<0,05)$. Z badań przeprowadzonych przez Skawińskiego, na podstawie wypełnionych ankiety, 77,5\% osób jest zdania, że spędzanie dużej ilości czasu w pozycji siedzącej istotnie oddziałuje na kształtowanie się postawy ciała [6].

Z otrzymanych wyników 87,5\% dzieci z nieprawidłowym poziomem wskaźnika BMI cierpi na wadę postawy, natomiast tylko 12,5\% przebadanych osób pomimo prawidłowej wartości wskaźnika BMI ma wadę postawy. Maciałczyk-Paprocka w swoich badaniach wykazała, że u ok. 74\% chłopców, którzy mieli otyłość i nadwagę występują wady postawy, u dziewczynek odsetek ten jest jeszcze wyższy i wynosi ok. 85\% $(\mathrm{p}<0,05)$ [4]. Nieprawidłowy wskaźnik BMI wpływa negatywnie na zaburzenia postawy ciała.

Z przeprowadzonych badań wynika, że ok. 66\% dzieci, które nie przestrzegają prawidłowych zasad noszenia plecaka (tornister nie waży więcej niż 10-15\% masy ciała, ma usztywnioną ściankę przylegającą do pleców oraz równe, szerokie szelki, cięższe rzeczy są umieszczone na dnie, lżejsze wyżej, tornister noszony jest na obu ramionach) ma zdiagnozowaną wadę postawy, natomiast ok. 33\% uczniów mimo, że przestrzega zasad noszenia tornistrów występują u nich wady postawy $(\mathrm{p}<0,05)$. Według Skawińskiego ok. 89\% dzieci w wieku szkolnym uważa, że masa tornistra oddziałuje w przyszłości na ich sylwetkę. 
Z kolei 5\% uczniów wyraża opinię, że waga tornistra w żaden sposób nie wpływa na postawę ciała. Ponadto $5 \%$ dzieci stwierdza, że nie ma pojęcia o tym czy masa plecaka ma wpływ na ich postawę. W dodatku ok. 48\% uczniów swój plecak nosi na obu ramionach, ok. 37\% tylko na jednym ramieniu. Pozostała część, czyli 22\% dzieci nie przykłada uwagi do tego w jaki sposób nosi plecak [6]. Na występowanie wady postawy ma wpływ nieprzestrzeganie zasad prawidłowego noszenia tornistra.

Idea profilaktyki zdrowotnej odnosząca się do uczniów jest skierowana na fakt, że ich zdrowie jest uzależnione nie tylko od okoliczności obejmujących medycynę, ale również od przyczyn pozamedycznych. Zaliczamy do nich między innymi pozycja ekonomiczno-społecznej najbliższych dziecka, pomoc obywatelską, otoczenie fizyczne i społeczne w placówce oświatowej jak również w gospodarstwie domowym [7].

Najbardziej sprzyjającym czasem do przeciwdziałania powstawaniu wad postawy jest dzieciństwo. Wpojone od najmłodszych lat zwyczaje odpowiednich postępowań zdrowotnych procentuje w wieku dorosłym witalnością, zręcznością i wyższym poziomem życia [6]. Działania zapobiegawcze stosowane za pomocą opieki zdrowotnej wśród dzieci są skierowane na jak najszybsze ujawnienie zaburzeń rozwoju dziecka [1].

Należy podkreślić, że niestety układ działalności profilaktycznokorekcyjnej w placówkach oświatowych ma niski poziom efektywności. Ponadto rodzice nie mają wiedzy o procedurze takich zajęć. Większość rodziców nie posiada również odpowiednich informacji ogólnych o wadach postawy ciała. Z powyżej przytoczonych powodów niezbędne jest wdrażanie w placówkach szkolnych działań zapobiegawczych powstrzymujących wady postawy, a także hamujących ich nasilanie. Istotną kwestią w analizowanym temacie jest również nauczanie rodziców $\mathrm{z}$ aspektów powstawania wad postawy. Staranność 
o polepszenie postawy ciała, odpowiednie jej formowanie i przeciwdziałanie czynnikom powodującym powstawanie wad postawy to ogromna próba sił dla rodziców, rehabilitantów czy pedagogów [8].

Profilaktykę wad postawy ciała można podzielić na pierwszorzędową i drugorzędową. Pierwszy z wyżej wymienionych typów profilaktyki swoim zakresem obejmuje wykluczanie przyczyn wpływających na postęp wad postawy oraz formowanie odpowiedniej sylwetki ciała. Z racji niebezpieczeństwa ujawniania się analizowanych wad w każdej fazie życia, czynności profilaktyczne są nieustannie konieczne na każdym etapie rozwoju dziecka. $Z$ tego powodu nieodzowna jest edukacja z zakresu czynności prozdrowotnych jak i również wartość odpowiedniej postawy ciała i sposób jej tworzenia. Ważną rolę odgrywają również trafna argumentacja do szerzenia takich ideologii, kompetencje i faktyczne działania zapobiegawcze. Szczególną rolę w środowisku szkolnym w kreśleniu postaw prozdrowotnych odgrywają nauczyciele wychowania fizycznego i biologii. Pierwsi z wyżej wymienionych nauczycieli mają za zadanie głównie pilnować jak najwyższej jakości lekcji wychowania fizycznego, mobilizować młode osoby do uprawiania sportu, a także dążyć do kompleksowego rozkwitu ruchowego uczniów. Wyjątkową misję w powstrzymywaniu wad postawy mają nauczyciele najmłodszych uczniów, ponieważ rozpoczęcie nauki powoduje ryzyko dla odpowiedniej postawy poprzez modyfikację trybu życia dziecka oraz przypadający wtedy pierwszy skok wzrostowy. Ci pedagodzy są odpowiedzialni za wybór adekwatnych do wzrostu mebli szkolnych, przypominanie dzieciom o odpowiedniej postawie w szkole czy przeprowadzanie aktywności fizycznych w młodszych grupach wiekowych [9].

Niestety u nielicznych dzieci, mimo prowadzenia działań zapobiegawczych ewoluują nieprawidłowości postawy ciała. W takim przypadku przymusowa jest profilaktyka drugorzędowa. W celu poprawy jej efektywności, istotne jest jak najszybsze wychwycenie ze 
społeczności uczniowskiej tych zagrożonych rozwojem zaburzeń postawy poprzez wykonywanie badań przesiewowych przez pielęgniarkę środowiskową, a także bilansów zdrowotnych przeprowadzanych przez lekarza pierwszego kontaktu. Pomyślność tych postępowań jest składową współdziałania pielęgniarki i lekarza. W czasie pomiędzy badaniami odsetek grupy dzieci powinien być bacznie obserwowany, zaś pozostali powinni być poddawani czynnościom korekcyjnym. Głównym założeniem przytoczonych czynności korekcyjnych jest powstrzymywanie dalszego rozwoju wady postawy jak również powstawania i umacniania negatywnych zmian wtórnych. Kluczowym detalem takiej metodyki jest formowanie na nowo zwyczaju odpowiedniej postawy, a także wtórna nauka dziecka przyjmowania i instynktownego utrzymywania poprawnego układu ciała. W opisywanych działaniach profilaktycznych wyjątkową rolę odgrywają nauczyciele wychowania fizycznego, ponieważ oni pierwsi mogą zaobserwować nieprawidłowości w postawie swoich uczniów. Ponadto muszą koniecznie pamiętać, aby dzieci z wadami postawy nie wykonywały ćwiczeń zabronionych, ale jednocześnie brały udział w zajęciach wychowania fizycznego. Produktywność działań zapobiegawczych przeciw powstawaniu wad postawy jest zależna od potrzeby zażyłej współpracy każdego z podmiotów powiązanych $\mathrm{z}$ otoczeniem nauczania i wychowania. $\mathrm{Z}$ tego właśnie powodu trafne jest przystępowanie do prób systemowego rozwiązania problemu poprzez aktywizację współdziałania pomiędzy młodymi osobami, ich rodzicami oraz pracownikami placówek szkolnych i służby zdrowia [9].

Występuje również profilaktyka trzeciorzędowa adresowana do osób cierpiących na wady postawy, u których nastąpiły już zmiany zarówno funkcjonalne jak i strukturalne. Odtworzenie odpowiedniej postawy dla wskazanej powyżej grupy ludzi jest nierealne. Wyłącznym zamierzeniem podjętych czynności jest zastopowanie postępu wady, 
a także osłabienie następstw poprzez redukowanie ich do jak najniższego poziomu [3].

Działania profilaktyczne dotyczące wad postawy wśród młodzieży szkolnej spełniane są poprzez:

- regularną troskę o utrzymywanie prawidłowej postawy ciała,

- systematyczne badanie stanu zdrowia,

- neutralizowanie przyczyn powodujących powstawanie wad,

- gwarantowanie dziecku właściwej dla jego osoby ilości aktywności fizycznej powodującej uniwersalny i regularny rozkwit fizyczny [9].

W otoczeniu dydaktycznym o zdrowie uczniów troszczy się pielęgniarka środowiskowa nauczania i wychowania. Do jej głównych obowiązków należy przede wszystkim przeprowadzanie i analizowanie testów przesiewowych, umożliwiających szybkie rozpoznanie kłopotów zdrowotnych. Wykonanie wyżej wymienionych czynności ułatwia pielęgniarce przyglądanie się procesowi dojrzewania wśród młodych osób. W zaistniałej sytuacji rozpoznanie komplikacji zdrowotnych ukazujących się wśród wyżej wymienionej grupy służy planowaniu specjalistycznej opieki nad problemami zdrowotnymi wskazanych osób [10].

\section{Wnioski}

1. Odsetek uczniów z wadami postawy sięga $24 \%$.

2. Najczęstszym rodzajem wad postawy u dzieci w wieku szkolnym w badanej grupie jest płaskostopie, natomiast najrzadziej koślawe kolana.

3. Brak aktywności fizycznej oraz nieprzestrzeganie zasad prawidłowego noszenia tornistra szkolnego ma istotny wpływ na występowanie wad postawy u dzieci w wieku szkolnym.

4. Nieprawidłowy wskaźnik BMI u dzieci wpływa negatywnie na zaburzenia postawy ciała. 


\section{Zalecenia dla praktyki pielęgniarskiej}

Rozpoznanie wady postawy na początku jej rozwoju, a także jej korekcja umożliwiają osiągnięcie zamierzonych wyników zdrowotnych, które istotnie zmniejszają destrukcyjność powstałych wad, jak również ich wpływ na jakość życia w dorosłym wieku.

\section{Bibliografia/Bibliography:}

1. Wawrzyniak A., Tomaszewski M., Mews J., Jung A., Kalicki B. Wady postawy u dzieci i młodzieży jako jeden z głównych problemów w rozwoju psychosomatycznym. Pediatr Med. Rodz 2017;13(1):73-77.

2. Szczepanowska-Wołowiec B., Drzał-Grabiec J., Sztandera P., Dudek J. Kotela I. Wady postawy w płaszczyźnie strzałkowej dzieci 10-12 letnich w województwa świętokrzyskiego. Studia Medyczne 2012;27(3):32.

3. Muchacka R., Pyclik M. Wady postawy u dzieci i młodzieży - charakterystyka i etiologia. Prace Naukowe WSZiP 2016; 37(1):69-87.

4. Maciałczyk-Paprocka K., Krzyżaniak A. Kotwicki T., Sowińska A., Stawińska-Witoszyńska B. Krzywińska-Wiewiorowska M., Przybylski J. Występowanie błędów w postawie ciała u uczniów poznańskich szkół podstawowych. Probl Hig Epidemiol 2012;9 (2):310- 312.

5. Białoszewski A. Kłak A. Szymański J. Raciborski F. Lusawa A. Tomaszewska A. Walkiewicz A. Samel-Kowalik P. Borowicz J. Samoliński B. Aktywność fizyczna a problemy układu ruchu dzieci w wieku wczesnoszkolnym u dzieci uczęszczających do klas pierwszych szkoły podstawowej na ternie miasta stołecznego Warszawa. Valetudinaria - Postępy Medycyny Klinicznej i Wojskowej 201; (16):20.

6. Skawiński D. Zaworska-Winiarska A. Sikora D. Horecka-Lewitowicz A. Szpringer M. Ocena poziomu wiedzy z zakresu profilaktyki wad postawy wśród dzieci i młodzieży. Studia Medyczne 2011; 21:16,17. 
7. Modrzejewska J., Malec Z. Wady postawy ciała uczniów w młodszym wieku szkolnym. Komunikaty i sprawozdania z badań/NIS 2017;3,63:86, 88-90.

8. Szczepanowska-Wołowiec B., Wołowiec P., Kotela P. Wady postawy populacji dzieci w wieku 10-12 lat na terenie gminy Masłów. Studia Medyczne 2010:17,41.

9. Górecki A., Kiwerski J., Kowalski I., Marczyński W., Nowotny J., Rybicka M., Jarosz U., Suwalska M., Szelachowska-Kluza W. Profilaktyka wad postawy u dzieci i młodzieży w środowisku nauczania i wychowania - rekomendacje ekspertów. Pol. Ann Med. 2009;16(1): 172-174.

10. Kocka K., Kachaniuk H., Bartoszek A., Fałdyga U., Charzyńska-Gula M. Najczęstsze problemy zdrowotne dzieci w wieku szkolnym - na przykładzie szkoły podstawowej i gimnazjum w Lublinie. Medycyna Ogólna i Nauki o Zdrowiu, 2013;19,4:508. 